\title{
Spread Sheet Solutions in Irrigation Canal Modeling help to achieve better Operational Performance in Major Irrigation Schemes
}

\author{
S.M. P. Siriwardana
}

\begin{abstract}
Levels of Operational performance in Major Irrigation Schemes have become a major concern to the scheme operators and scheme managers. To achieve better levels of performance a situation analysis close to reality is needed when they schedule their irrigation deliveries in the canals. Various methods are being practiced by the system operators in their scheduling processes. Most of the methods are not in conformity with the scheme objectives and water rights of the farmers. So there is a vacuum demanding a better solution which can be applied as a tool for planning and monitoring irrigation schedules taking in to account the instantaneous changes in climatic and cropping conditions.
\end{abstract}

In order to fulfill the above requirements, a mathematical model was developed using spread sheets and Visual Basic Applications. This model creates irrigation schedules for Primary, Secondary and Tertiary canals by considering instantaneous conditions such as cropping data, metrological data, reservoir levels and canal properties.

This model was tried out in the Mahaweli System C during six consecutive cultivation seasons and a better water productivity could be obtained. Mahaweli System C covers cultivated paddy (Rice) land of 24,100 ha and this model covered 16,772 ha of that land area..

Keywords: Irrigation Schedules, Operational Targets, System efficiency, Water Productivity

\section{Introduction}

The management of an irrigation system has as its purpose the delivery of water to agricultural land at such times and in such quantities so as to enable the irrigator to produce the largest and the best crop. The success of the manager is largely measured by the success of the farmer (F.H.Newell, 1916).

It indicates the significance of irrigation water management in an irrigation scheme towards producing optimum productivity. In order to achieve this through irrigated agriculture, operational performance of the irrigation system has to be maintained at a higher level or close to its potential.

The performance of many irrigation and drainage systems is significantly below their potential due to a number of shortcomings which include;

- Poor initial design due to inadequate operational specifications, or design assumptions which were not or could not be fulfilled after the construction and commissioning of the work;
- Distribution system layout not adequately reflecting the existing land tenure or family/community associations in farm management;

- Poor, improper or inadequate management environments;

- Poor management system within the managing organisations.

The most obvious manifestation of these shortcomings is the unreliability of the main system water supply and poor maintenance practices (Malano and van Hofwegen, 1999).

The unreliability of water supply leads to lower the efficiency level of an irrigation scheme. Yet making irrigation water supply a reliable and efficient service to the users is not so simple. It needs several internal factors such as scheduling, operation, monitoring,

Eng. S.M.P. Siriwardana, C.Eng., MIE(Sri Lanka), NDT (Civil), IESL (Part II), M.Sc. (Netherland), Procurement Specialist, Kandy City Wastewater Management Project, Former Deputy Resident Project Manager (Engineering), System C, Mahaweli Authority of Sri Lanka. 
maintenance, recording etc. and external factors such as change of weather, change of crop related environment, attitudes of water users etc. to be addressed strategically.

Properly predicted irrigation schedules, mathematically derived operation targets, appropriate operational techniques and water users' participation in seasonal planning lead to better efficiencies of irrigation schemes to provide reliable, equitable and adequate irrigation services to the water users.

The preparation of predicted irrigation schedules taking into account the weather related changes and the crop related changes in the schemes, on a weekly or daily basis is very time consuming and needs inputs from technical staff. Setting operational targets for such revised schedules is again very time consuming and needs inputs from technical staff.

Hence, developing an adequate mathematical instrument capable of addressing the above mentioned technical difficulties is the key to achieving better scheme performance of irrigation water supplies.

\section{Background}

Mahaweli System C is a newly developed major irrigation scheme coming under the Mahaweli Ganga Development Programme.

It is situated in the east-central part of Sri Lanka on the right bank of the Mahaweli Ganga, with a gross area of 66,700 ha of land of which 24,100 ha is supplied by gravity irrigation. There are approximately 25,500 settler families in the scheme's command area and these families are engaged in agriculture and reside in villages consisting of 20 to 30 home steads located within the settlement areas. The command area lies between the Mahaweli River and the main canal linking a series of large and medium size reservoirs along the canal. These reservoirs receive surface run-off from their own catchments, in addition to receiving augmentation flows from the canal. This design, adopted in the original development of the irrigation system, enables the minor reservoirs to provide dual functions in receiving return flows and enhancing the flexibility of the water delivery in the canals.

The scheme is divided into six zones, numbered 1 to 6 sequentially, for the purpose of management and administration. Zone 1 area is supplied by an existing irrigation system and does not come under the management of the Mahaweli Authority of Sri Lanka (MASL) operated System C(Analysis Report, 2004).

System $C$ area spans over the Dry zone and the Intermediate zone. Zone 1 and a part of Zone 2 lie in the Intermediate Zone, whilst the other area lies in the Dry Zone.

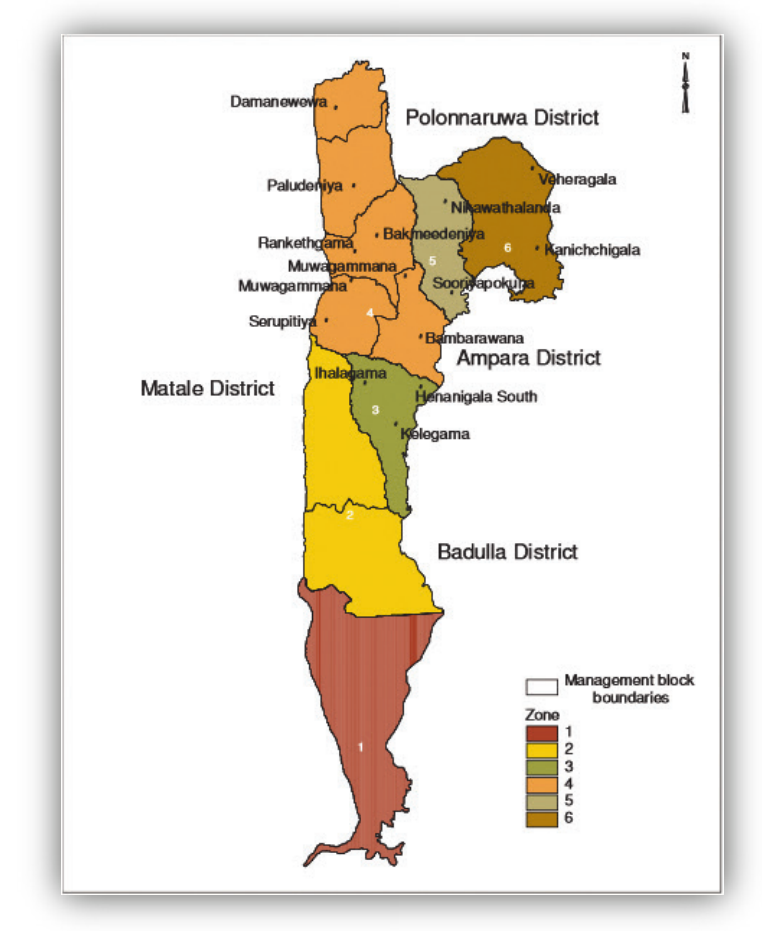

Figure 1 - Location Map of System C

The rainfall pattern is different from that of most parts of the dry and the intermediate zones in the island with heavy rainfall experienced in the Maha season, particularly between the months of November and January. Approximately $80 \%$ of the rainfall occurs during the Maha season. On average, rainfall exceeds $\mathrm{ET}_{0}$ only between the months of October and February.

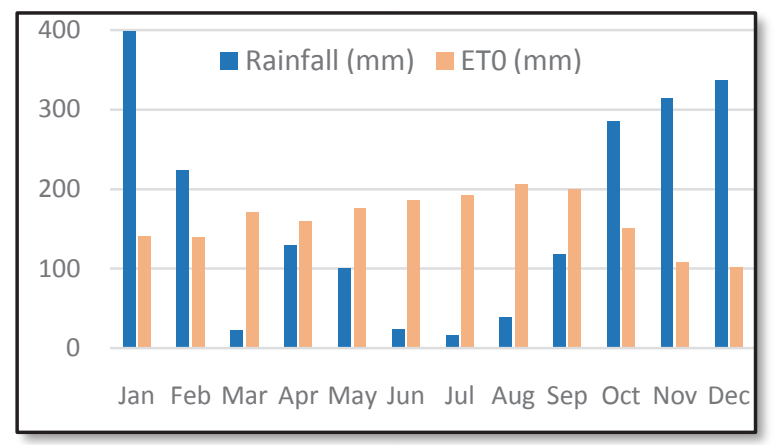

Figure 2 - Monthly Average Rainfall and ET0 in System C

The temperature is characterised by a considerable monthly variability ranging from a minimum of $20^{\circ} \mathrm{C}$ in February to a maximum of $36^{\circ} \mathrm{C}$ during the period from June to August. 
The monthly mean value of the relative humidity varies from $52 \%$ to $88 \%$ and the values are comparatively lower between June and September. The monthly mean wind velocity is observed at about $2.5 \mathrm{~km} / \mathrm{h}$ between November and May and at about $4.0 \mathrm{~km} / \mathrm{h}$ or more between June and September. Monthly mean sunshine hours are observed at 6.0 hours/day or more between February and October and at relatively shorter periods during other months (Operation and Maintenance Manual, System C, 1991).

\subsection{Problem Statement}

The first operation of the system was done in 1983 with irrigation water delivery to Zone 2. Then from time to time the operational area was expanded with the completion of the irrigation facilities of the area. By 1994, the project facilities of System C were substantially completed.

With the development of the area, irrigation water delivery in System C was done by two Main Canal Units (MCUs)aiming at an efficient water management. MCU 1 served Zone 2, where the farming area was fed by Ulhitiya LB Main Canal 1 \& Rathkinda LB sluice and MCU 2 served Zone 3-6, where the farming area was fed by Rathkinda RB Main Canal 2.

However farmers' dissatisfaction of water deliveries was a concern in the scheme. Non uniformity of water deliveries was the main issue. The analysis of the results of the field survey done prior to implementing the Mahaweli Upgrading Project (MUP) confirms this situation. This survey was carried out by Nippon Koei Consultants between May and June 2001. The results were published in October 2004, in the 'Analysis Report of the First Benchmark Survey of Mahaweli System C Upgrading Project' published by IWMI.

In this analysis report, the following outcomes were reported.

> Problems of water shortage (34\% overall) were identified as significant in four villages, in which over $60 \%$ of farmers had identified this as a major constraint.

$>$ A slight majority of farmers, 55.77\% (Table 26) indicated that irrigation supplies generally arrived in a timely manner.

$>$ A slightly larger majority, 60.46\% (Table 27), of farmers expressed general satisfaction with the quantity of irrigation deliveries.

While problems with equity, adequacy and reliability of irrigation supplies are the clearly perceived problems by the farmer communities, the causes of these problems often occur at a location remote from the village. Failures of canal structures, inappropriate, unscheduled or unauthorized diversions in upstream locations are all operational problems that result in failures to deliver the expected level of service at the farmer level. (Analysis Report, 2004).

Although the farmers experience improper service of water delivery, the amount of irrigation water supplied at scheme level was higher than the estimated amounts of the previous years.

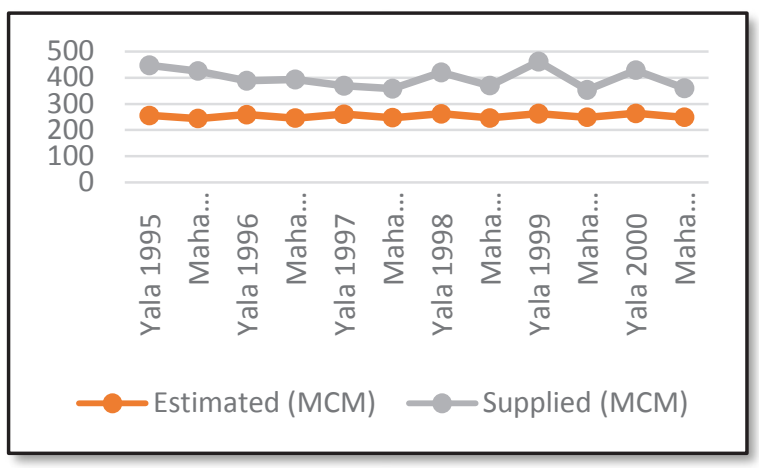

Figure 3 - Irrigation Water Usage, Estimated and Supplied (Source - System C, FMU records)

It shows that the irrigation water supply in the Scheme has not been properly managed. The responsibility of the operation managers for the proper water management is questionable.

This is not a healthy situation as there could be future challenges in the form of an increasing interest from other competing sectors for the available fresh water resources.

It is realized that there is a need for an efficient methodology capable of scheduling, rescheduling, hassle free operation, monitoring, and maintaining equity, reliability and adequacy of irrigation deliveries.

\section{Objectives}

This paper presents the spread sheet model developed for scheduling, setting operational targets and monitoring the irrigation deliveries of the command area under Rathkinda RB Main Canal 2 of System C. This area covers dry zone (Zones 3-6) of the Scheme having 16,772 ha of farm area spread over six Management Blocks namely Medagama, Sandunpura, Siripura, Nuwaragala, Mahawanawela and Veheragala. The design capacity of the canal is $50 \mathrm{~m}^{3} / \mathrm{s}$ and almost all the canals in the network are earthen canals. 


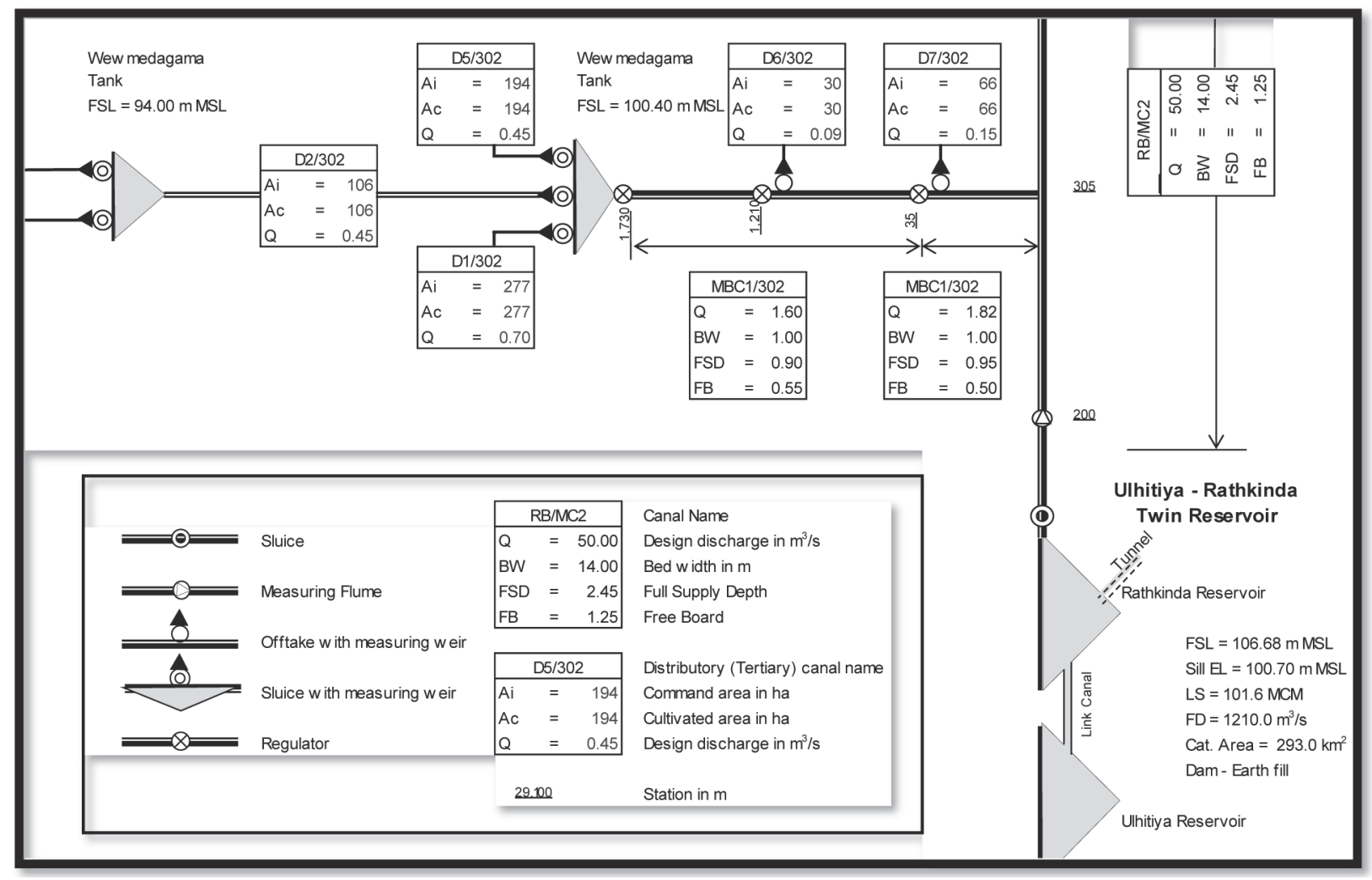

Figure 4 - Part of the Canal Layout at the Head of the Rathkinda RB Main Canal 2

This model provides facilities to;

1. Schedule irrigation deliveries at Primary, Secondary and Tertiary levels
2. Re-schedule irrigation deliveries as per instantaneous/periodic changes of weather, crop and storage in the intermediate reservoirs

Table 1 - Primary and Secondary level Irrigation Infrastructure Facilities under RB Main Canal 2

\begin{tabular}{|l|c|c|c|c|c|}
\hline \multicolumn{1}{|c|}{ Category } & Nos. & $\begin{array}{c}\text { Length } \\
\mathbf{( k m )}\end{array}$ & $\begin{array}{c}\text { Max Discharge } \\
(\mathbf{m 3} / \mathbf{s})\end{array}$ & $\begin{array}{c}\text { No. of } \\
\text { Reservoirs }\end{array}$ & $\begin{array}{c}\text { No. of } \\
\text { Structures }\end{array}$ \\
\hline Main Canal & 1 & 17.4 & 50.0 & 3 & 40 \\
\hline Branch Canal & 5 & 45.4 & 27.0 & 7 & 157 \\
\hline $\begin{array}{l}\text { Minor Branch } \\
\text { Canal }\end{array}$ & 13 & 59.6 & 4.7 & 4 & 249 \\
\hline \multicolumn{1}{|c|}{ Total } & $\mathbf{1 9}$ & $\mathbf{1 2 2 . 4}$ & & $\mathbf{1 4}$ & $\mathbf{4 9 1}$ \\
\hline
\end{tabular}

Note 1 - Source: RPM's Office, System C

3. Set operational (hydraulic) targets at each and every measuring structure and at control structures including intermediate reservoirs

4. Monitor the performance at management Block level and at tertiary canal level

5. Create daily, weekly and seasonal reports

\section{Approach}

The following approach is used to create the mathematical model. which is nronosed to 11se as a tool for managing irrigation water deliveries made under Rathkinda RB Main Canal 2.

- Literature study is done to find appropriate formulae and their limitations of use

- Necessary flow charts are drawn

- Spread sheets are developed in order to perform calculations for the model

- Visual Basic interfaces are added for making the model user friendly

- Model is field tested for verification of results 


\section{Literature Study}

The literature study was carried out so as to find out the best suit formulae and data to bring the model close to the reality.

\subsection{Scheduling Irrigation Deliveries}

The main crop in the System Cfarm fields is lowland paddy. Almost all areas are planted with paddy for cultivation seasons, Maha and Yala (99.2\% paddy in 2001/2002 Maha and 98.9\% paddy in 2001 Yala). Cultivation of Other Field Crops (OFC) is still very limited. In other words, it is a monoculture-cropping pattern (Siriwardana, 2002).

Hence only the literature for calculating Irrigation Water Requirements (IWR) for low land paddy was studied.

In Section 4.2 of the O\&M Manual (Operation and Maintenance Manual, System C, 1991), the methodology and derived tables are provided to calculate IWR.

IWR for paddy crop is identified in two stages, namely land preparation stage and growing stage. IWR for land preparation period is calculated using the formula below.

$\mathrm{L}_{\mathrm{p}}=\mathrm{L}_{\mathrm{s}}+\mathrm{L}_{\mathrm{t}}+\mathrm{E}+\mathrm{P}_{\mathrm{d}}+\mathrm{P}_{\mathrm{s}}$

where, $\mathrm{L}_{\mathrm{p}}$; Water requirement for land

$$
\begin{aligned}
& \mathrm{L}_{s} \text {; Water requirement for land } \\
& \text { soaking in } \mathrm{mm} \\
& \mathrm{L}_{\mathrm{t}} \text {; Water requirement for land } \\
& \text { tillage in } \mathrm{mm} \\
& \text { E; evaporation rate during land } \\
& \text { preparation in } \mathrm{mm} \\
& \mathrm{P}_{\mathrm{d}} ; \quad \text { deep percolation rate during } \\
& \text { land preparation in } \mathrm{mm} \\
& \mathrm{P}_{\mathrm{s}} \text {; } \quad \text { seepage through bund during } \\
& \text { land preparation in } \mathrm{mm}
\end{aligned}
$$

Based on the following assumptions and data the IWR for land preparation is calculated and is shown in Table 3.

1) Plough layer thickness is $200 \mathrm{~mm}$ and air phase ratio is 0.2 (3\% cannot be replaced with water)

2) Ground water table is $1.0 \mathrm{~m}$ below the surface

3) Evaporation rate is $3.0 \mathrm{~mm} /$ day as per the observations of the Agriculture Research Station, Girandurukotte.

4) Deep percolation rates are as per Table 2

5) Land Soaking period is one week and the period for irrigation after land soaking is three weeks

6) Seepage loss through bund is to be neglected.
Table 2 - Estimated Deep Percolation Rates (Table 4-1 of the O\&M Manual)

\begin{tabular}{|l|c|}
\hline $\begin{array}{l}\text { Management } \\
\text { Block }\end{array}$ & $\begin{array}{l}\text { Weighted mean value of } \\
\text { Deep Percolation }(\mathrm{mm} / \mathrm{d})\end{array}$ \\
\hline Medagama & 3.7 \\
\hline Sandunpura & 3.9 \\
\hline Siripura & 3.8 \\
\hline Nuwaragala & 3.9 \\
\hline Mahawanawela & 3.5 \\
\hline Veheragala & 4.2 \\
\hline
\end{tabular}

Using the above estimates and values, the IWR for the land preparation of the farm area of each Block is estimated and given in Table 3.

Table 3 - IWR for land preparation (Table 4-2 of O\&M Manual)

\begin{tabular}{|l|c|c|c|}
\hline $\begin{array}{l}\text { Management } \\
\text { Block }\end{array}$ & $\begin{array}{l}\text { Land } \\
\text { Soaking }\end{array}$ & $\begin{array}{l}\text { Land } \\
\text { Tillage }\end{array}$ & $\begin{array}{l}\text { Total } \\
(\mathrm{mm})\end{array}$ \\
\hline Medagama & 170 & 210 & 380 \\
\hline Sandunpura & 170 & 215 & 385 \\
\hline Siripura & 170 & 215 & 385 \\
\hline Nuwaragala & 170 & 215 & 385 \\
\hline Mahawanawela & 170 & 210 & 380 \\
\hline Veheragala & 170 & 220 & 390 \\
\hline
\end{tabular}

IWR for the growing period of the crop is estimated using Figure 5.

$\operatorname{IWR}=\left(\mathrm{ET}_{\mathrm{c}}+\mathrm{P}_{\mathrm{d}}\right) / \mathrm{e}_{\mathrm{a}}$

Where, $\mathrm{ET}_{\mathrm{c}} ; \quad \mathrm{ET}_{0} \times \mathrm{k}_{\mathrm{c}}$

$\mathrm{ET}_{0} ; \quad$ Reference crop evapotranspiration $\mathrm{mm} /$ day

$\mathrm{k}_{\mathrm{c}}$; $\quad$ Crop Coeficient

$\mathrm{P}_{\mathrm{d}}$; deep percolation $\mathrm{mm} /$ day

$\mathrm{e}_{\mathrm{a}} ; \quad$ application efficiency

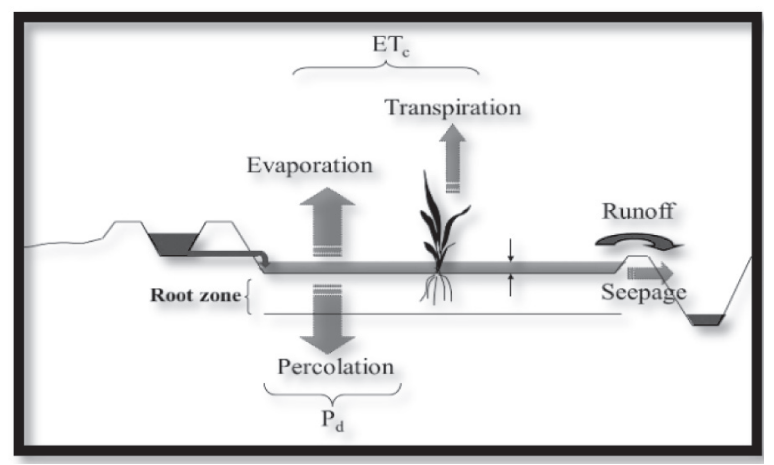

Figure 5 - Phenomena for estimation of CWR

The reference crop evapotranspiration values given in the manual are tabulated in Table 4.

Table 4 - Reference Crop Evapotranspiration $\left(\mathrm{ET}_{0}\right)$

\begin{tabular}{|l|l|c|}
\hline Season & Month & $\begin{array}{l}\mathrm{ET}_{0} \text { for zone 3-6 } \\
(\mathrm{mm} / \text { day })\end{array}$ \\
\hline Maha & Jan & 4.5 \\
\hline & Feb & 5.0 \\
\hline & Mar & 5.5 \\
\hline Yala & Apr & 5.3 \\
\hline
\end{tabular}




\begin{tabular}{|l|l|l|}
\hline & May & 5.7 \\
\hline & Jun & 6.2 \\
\hline & Jul & 6.2 \\
\hline & Aug & 6.6 \\
\hline & Sep & 6.7 \\
\hline Maha & Oct & 4.9 \\
\hline & Nov & 3.6 \\
\hline & Dec & 3.3 \\
\hline
\end{tabular}

Note 2 - Data Table 4-3 of OEM Manual

Crop coefficients for Initial, Development, Mid and Late stages are given in Table 5.

Table 5 - Growth Stages and Crop Coefficients

\begin{tabular}{|l|l|l|l|l|l|}
\hline \multirow{2}{*}{ Crop } & \multicolumn{4}{|c|}{ Growth Stages } \\
\cline { 3 - 6 } & & Init. & Dev. & Mid & Late \\
\hline $\begin{array}{l}\text { Lowland } \\
\text { Paddy }\end{array}$ & Days & 30 & 40 & 45 & 20 \\
\cline { 2 - 6 } & kc & 1.00 & 1.15 & 1.20 & 0.90 \\
\hline $\begin{array}{l}\text { Lowland } \\
\text { Paddy }\end{array}$ & Days & 20 & 30 & 30 & 25 \\
\cline { 2 - 6 } & kc & 1.00 & 1.15 & 1.20 & 0.90 \\
\hline
\end{tabular}

Note 3 - Data Table 4-4 of OEM Manual

Deep percolation rates given in Table 2 and the field application efficiency suggested in the Manual are used for calculating the IWR.

Although above procedures are given in the O\&M Manual, the simplified scheduling rate of flows at tertiary canal sluice level is being used by the scheme operators in System C. It was identified by the author during his research in 2001 as indicated below.

At the land preparation stage, they allocate 2.1 $\mathrm{l} / \mathrm{s} / \mathrm{ha}$ at the distributory canal head and 1.4 $\mathrm{l} / \mathrm{s} / \mathrm{ha}$ at all the other stages without considering the climatic conditions (Siriwardana, 2002).

\subsection{Effective Rainfall}

Irrigation water is delivered to farm fields as there is insufficient effective rainfall to grow crops for producing reasonable yields.

If there is a significant amount of effective rainfall during the irrigation of farms, the irrigation deliveries are adjusted in order to save water in the upstream storage reservoirs.

Effective rainfall is defined as "a part of the total rainfall considered effective in satisfying the total or part of requirements for land preparation, crop water requirement and farm losses" (Operation and Maintenance Manual, 1991).

To estimate effective rainfall through a formula, several formulas have been developed empirically based on long experience with certain conditions which may be different from others. Ponrajah suggested the following formulae for estimating the monthly effective rainfall.
For lowlands

Effective Rainfall, $R e=0.67 \times(R-25)$

For uplands

Effective Rainfall, $\mathrm{Re}=0.67 \times(\mathrm{R}-6)$

where, $R$ is value of rainfall (Ponrajah, 1984).

For the purpose of canal operation, the above formulae are not suitable due to the long periods involved. Therefore, the following method used in India may be used to estimate daily or short term effective rainfall for paddy cultivation $(\mathrm{FAO}, 1974)$.

A rainfall less than $6 \mathrm{~mm}$ /day is considered as ineffective. Similarly, any amount over 75 $\mathrm{mm} /$ day and rainfall in excess of $125 \mathrm{~mm}$ per 10 days are treated as ineffective.

\subsection{Conveyance Losses}

Conveyance loss is defined as the water loss due to seepage, leakage, operational waste and evaporation from canals while conveying irrigation water from the sluice to the farm. Seepage losses in earthen canals and evaporation losses in dry zones are significant among other losses, where leakages and operational losses could be eliminated or minimised.

The Moritz formula can be used to estimate seepage loss depending on the type and flow area (USBR, 1967).

$\mathrm{S}=0.01154 \times \mathrm{C} \times \sqrt{Q} / V$

where, S; seepage loss in cumec $/ \mathrm{km}$

Q; canal discharge in cumec

$\mathrm{V}$; mean velocity of flow in $\mathrm{m} / \mathrm{sec}$

C; Moritz coefficient

\subsection{Discharges at Measuring Structures}

The Manning Formula and Kennedy's formula are used for the design of the canals in the Scheme.

There are different types of measuring structures in the Primary, Secondary and Tertiary canal systems in the Rathkinda RB main Canal 2 of the Scheme. They are;

- Trapezoidal Throated Flumes

- Gated regulators and

- Weir type measuring devices

Trapezoidal Throated flumes and Gated regulators are used in the Main, Branch and Minor Branch canals where discharges are high. Trapezoidal Throated flumes are used to measure the discharges at $\mathrm{d} / \mathrm{s}$ of the reservoir sluices of such canals. 
In the Appendix - 2F of the O\&M Manual, the designed and observed Head - Discharge curves of the flumes are provided.
Weir type measuring devices are provided at the Tertiary turnouts in the scheme. They have been field tested and coefficients are given in the O\&M Manual.

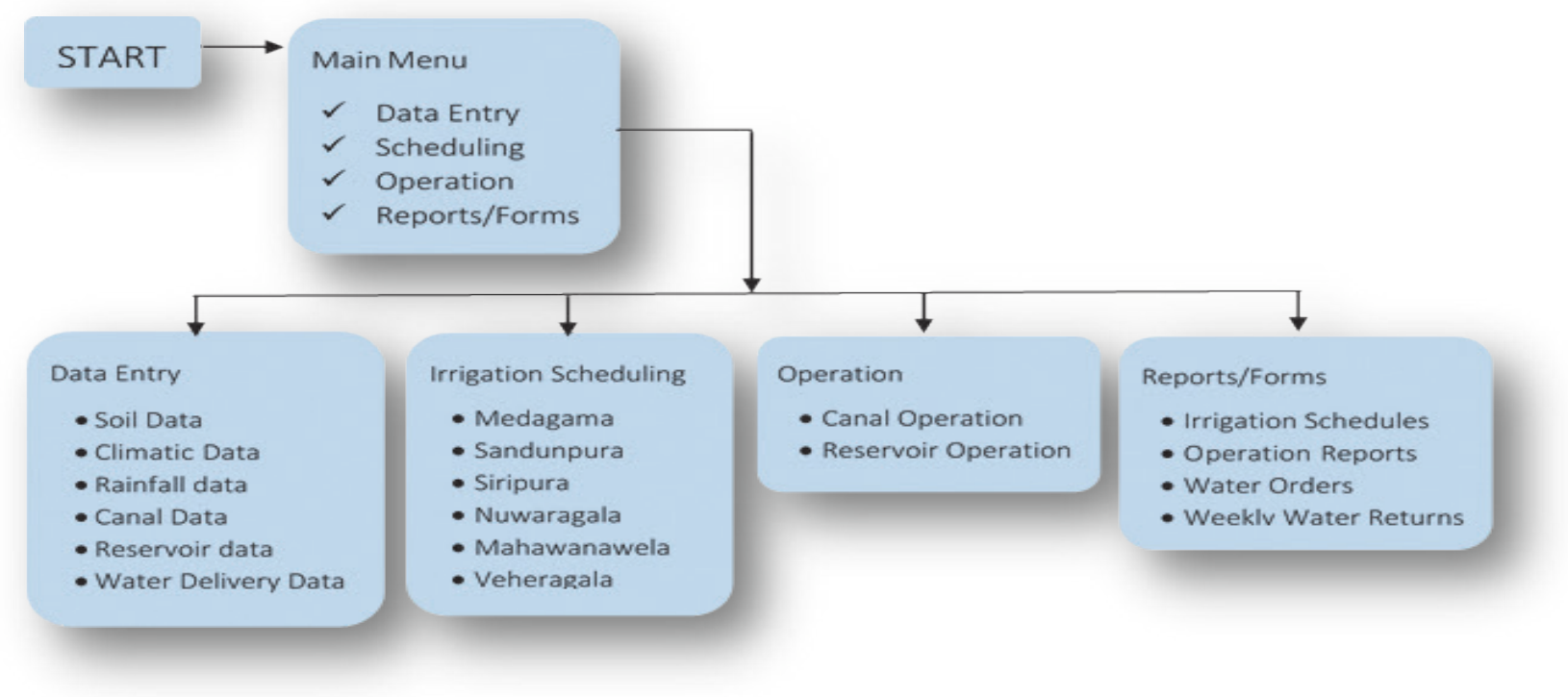

Figure 6 - Layout and main elements of the Model

The specific discharge (the discharge through unit width of the weir in $1 / \mathrm{s} / \mathrm{m}), \mathrm{q}_{\mathrm{u}}$;

$\mathrm{q}_{\mathrm{u}}=a \times \mathrm{H}^{\mathrm{b}}$

Coefficients $a, b$ and the weir width of each and every tertiary canal are given in Appendix - 2I of the O\&M Manual.

\subsection{Control Structures}

Facilitating the water conveying from head sluice to the farm plots along the different types of control structures of the canals is provided in the system. They are shown in the water distribution diagrams in Appendix - 2B of the O\&M Manual. A part of a diagram is shown in Figure 4.

Sluice gates, Gated regulators, Weir type regulators, Side spills, Offtakes and intermediate reservoirs are significant among them.

\section{Model}

The mechanism and the facilities of the Model are briefly mentioned below.

The required programme flow charts of the elements to create the Model are first drawn. After creating the Model, the basic data is fed into the Model permitting it to work. The conceptual flow diagram of the element 'Reservoir Operation' is shown in Appendix 1.

\subsection{Scheduling Irrigation Deliveries}

Irrigation Water Requirements (IWR) are calculated using Tables 3, 4, 5 and Equation (2). Following irrigation efficiencies are used:

- Application efficiency $90 \%$

- Tertiary system efficiency $80 \%$

It is noticed that the monthly $\mathrm{ET}_{0}$ values given in the O\&M manual are quite high compared to the $\mathrm{ET}_{0}$ values calculated using the software CROPWAT 4.0 (FAO). The values given by CROPWAT are chosen for IWR calculations. The weekly $\mathrm{ET}_{0}$ values are derived by fitting a curve to the monthly data. The relevant values for each 52 weeks of the year are thereby obtained.

Sample calculation:

Calculate IWR at tertiary canal head for lowland paddy crop at development stage grown in Yala season. This is the $6^{\text {th }}$ week after sowing and is the last week of June. Area grown under this tertiary canal, D1/411 (Sandunpura) is 121 ha and weir width of the canal is $1.98 \mathrm{~m}$.

Eqn (2),

$$
\begin{aligned}
& \text { IWR }=\left(\mathrm{ET}_{\mathrm{c}}+\mathrm{P}_{\mathrm{d}}\right) / \mathrm{e}_{\mathrm{a}} \\
& =\left(\left(\mathrm{ET}_{0} \times \mathrm{kc}\right)+\mathrm{P}_{\mathrm{d}}\right) / \mathrm{e}_{\mathrm{a}} \\
& =((5.0 \times 1.15)+3.9) /(90 \%) \\
& =10.7 \mathrm{~mm} \text { at farm inlet }
\end{aligned}
$$

After applying tertiary system efficiency,

$$
\text { IWR }=13.4 \mathrm{~mm} \text { at tertiary canal head }
$$

As per operational methods of the Scheme, the irrigation water deliveries at tertiary canal 
offtakes are of the continuous supply type. The discharge at tertiary canal offtake should be known. The discharge required for one hectare is calculated first and then the discharge required for the total area grown is calculated.

$$
\begin{aligned}
& =0.00155 \text { cumecs } \\
& =1.61 / \mathrm{s} / \mathrm{ha}
\end{aligned}
$$

Hence, $Q=121 \times 1.6 \mathrm{l} / \mathrm{s} / \mathrm{ha}$

$$
=193.6 \mathrm{l} / \mathrm{s} / \mathrm{ha}
$$

\begin{tabular}{|c|c|c|c|c|c|c|c|c|c|c|c|c|}
\hline \multirow{3}{*}{\multicolumn{5}{|c|}{$\begin{array}{c}\text { Seasonal Operation Plan for the } \\
\text { Cultivation Season - Maha 2005/06 }\end{array}$}} & \multirow{3}{*}{ Soil : } & WD/RBE (\%) & 49 & \multirow{3}{*}{ Crop : } & \multirow{3}{*}{\begin{tabular}{|c|}
$3-31 / 2$ \\
Months low \\
land paddy
\end{tabular}} & \multirow{3}{*}{\multicolumn{3}{|c|}{ Sandunpura Block }} \\
\hline & & & & & & ID/RBE (\%) & 51 & & & & & \\
\hline & & & & & & LHG (\%) & 0 & & & & & \\
\hline \multirow[t]{2}{*}{ Canal Name } & \multirow{2}{*}{$\begin{array}{c}\text { Weir } \\
\text { Width } \\
(m)\end{array}$} & \multirow{2}{*}{$\begin{array}{c}\text { Cultivated } \\
\text { Extent } \\
\text { (ha) }\end{array}$} & \multicolumn{2}{|c|}{$\begin{array}{c}\text { Land Preparation } \\
(20 \text { Oct - } 20 \text { Nov) }\end{array}$} & \multicolumn{2}{|c|}{$\begin{array}{c}\text { Initial } \\
\text { (21 Nov-11 Dec) }\end{array}$} & \multicolumn{2}{|c|}{$\begin{array}{c}\text { Development } \\
\text { (12 Dec - 08 Jan) }\end{array}$} & \multicolumn{2}{|c|}{$\begin{array}{c}\text { Mid } \\
\text { (09 Jan - 05 Feb) }\end{array}$} & \multicolumn{2}{|c|}{$\begin{array}{c}\text { Late } \\
\text { (06 Feb - 05 Mar) }\end{array}$} \\
\hline & & & $\mathrm{H}(\mathrm{cm})$ & $Q(1 / s)$ & $\mathrm{H}(\mathrm{cm})$ & $Q$ (1/s) & $\mathrm{H}(\mathrm{cm})$ & $Q(1 / s)$ & $\mathrm{H}(\mathrm{cm})$ & $Q$ (I/s) & $\mathrm{H}(\mathrm{cm})$ & $Q$ (I/s) \\
\hline$D 1 A / 411$ & 1.92 & 92 & 13.2 & 184.0 & 8.7 & 96.6 & 9.8 & 116.8 & 10.4 & 127.9 & 9.7 & 115.0 \\
\hline$D 1 / 411$ & 1.98 & 121 & 15.4 & 242.0 & 10.2 & 127.1 & 11.5 & 153.7 & 12.2 & 168.2 & 11.4 & 151.3 \\
\hline$D 2 / 411$ & 1.91 & 79 & 12.0 & 158.0 & 7.9 & 83.0 & 8.9 & 100.3 & 9.5 & 109.8 & 8.8 & 98.8 \\
\hline$T / / 411$ & 2.37 & 163 & 16.6 & 326.0 & 11.0 & 171.2 & 12.4 & 207.0 & 13.1 & 226.6 & 12.3 & 203.8 \\
\hline$D 4 / 411$ & 2.96 & 203 & 16.6 & 406.0 & 10.9 & 213.2 & 12.4 & 257.8 & 13.1 & 282.2 & 12.3 & 253.8 \\
\hline$D 5 / 411$ & 2.69 & 152 & 14.6 & 304.0 & 9.7 & 159.6 & 10.9 & 193.0 & 11.6 & 211.3 & 10.8 & 190.0 \\
\hline$D 6 / 411$ & 1.90 & 113 & 15.1 & 226.0 & 10.0 & 118.7 & 11.3 & 143.5 & $12.0^{\circ}$ & 157.1 & 11.2 & 141.3 \\
\hline
\end{tabular}

Then, $Q_{\text {ha }} \quad=\frac{13.4 \times 10^{-3} \times 10^{4}}{(24 \times 60 \times 60)}$

Figure 7 - Sample of Operational Schedule prepared by the Model (Part of Sandunpura Block)

The canal discharges are not directly measured at the offtakes when deliveries are made. The measuring weir is used for this purpose and the discharge is converted to the hydraulic head at $\mathrm{u} / \mathrm{s}$ to the weir. This is done using the weir equation- Equation (6).

Specific discharge, $\mathrm{q}_{\mathrm{u}}=a \times \mathrm{H}^{\mathrm{b}}$

As per Manual the values of coefficients $a$ and $b$ for this specific canal are 2.22 and 1.55 respectively. Hence,

$$
\begin{aligned}
\mathrm{H} & =\left(\frac{193.6 \times 10^{-3}}{1.98 \times 2.22}\right)^{1 / 1.55} \mathrm{~m} \\
& =0.1334 \mathrm{~m} \\
& =13.3 \mathrm{~cm}
\end{aligned}
$$

The irrigation water delivery schedule during the last week of June in the Yala season for the tertiary canal D1/411 is simplified to the operators to deliver water at $13.3 \mathrm{~cm}$ hydraulic head at the weir during the week.

The irrigation schedules for all the tertiary canals fed through Rathkinda Main Canal 2 are calculated using spread sheets within minutes of entering the date of the first water delivery scheduled for a specific cultivation season. It saves a considerable amount of inputs from Engineering Assistants and Engineers of the Scheme.

\subsection{Operation Schedules}

Operation Schedules are prepared by the Model once the irrigation schedules are prepared. The conveyance losses of the Main \& Branch canals are calculated and added to the canal discharge at the relevant measuring structures. The value of Moritz coefficient, C taken for canals in System C is 0.66 for Sandy loam.

The Schedules are prepared based on the operational methodology of the Scheme, i.e. continuous deliveries in the main system and rotational deliveries in the tertiary system.

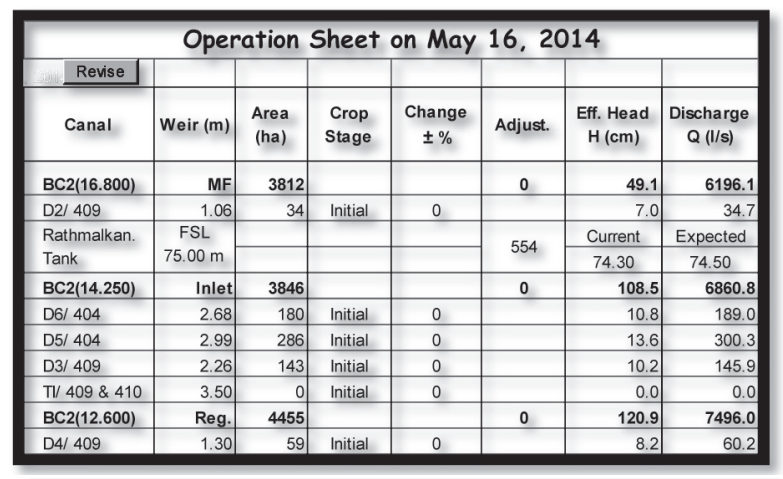

Figure 8 - Operation Sheet prepared by the Model (Part of)

\subsection{Re-Scheduling}

Any relevant change or update done in the data sheets makes necessary the recalculation of the irrigation schedules. Then the operation schedule is revised automatically. The Model has the facility to apply \% reductions to any of the block areas for re-scheduling. 


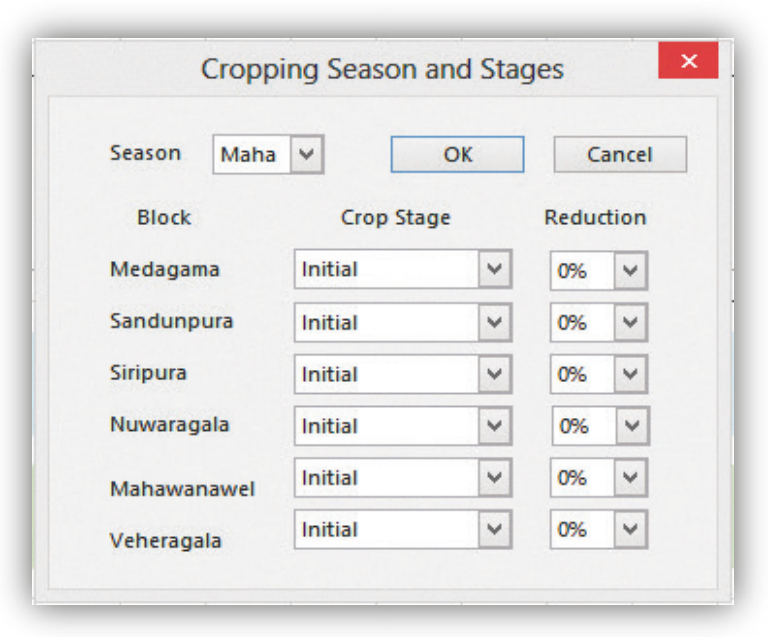

Figure 9 - Facility to apply \% Reduction

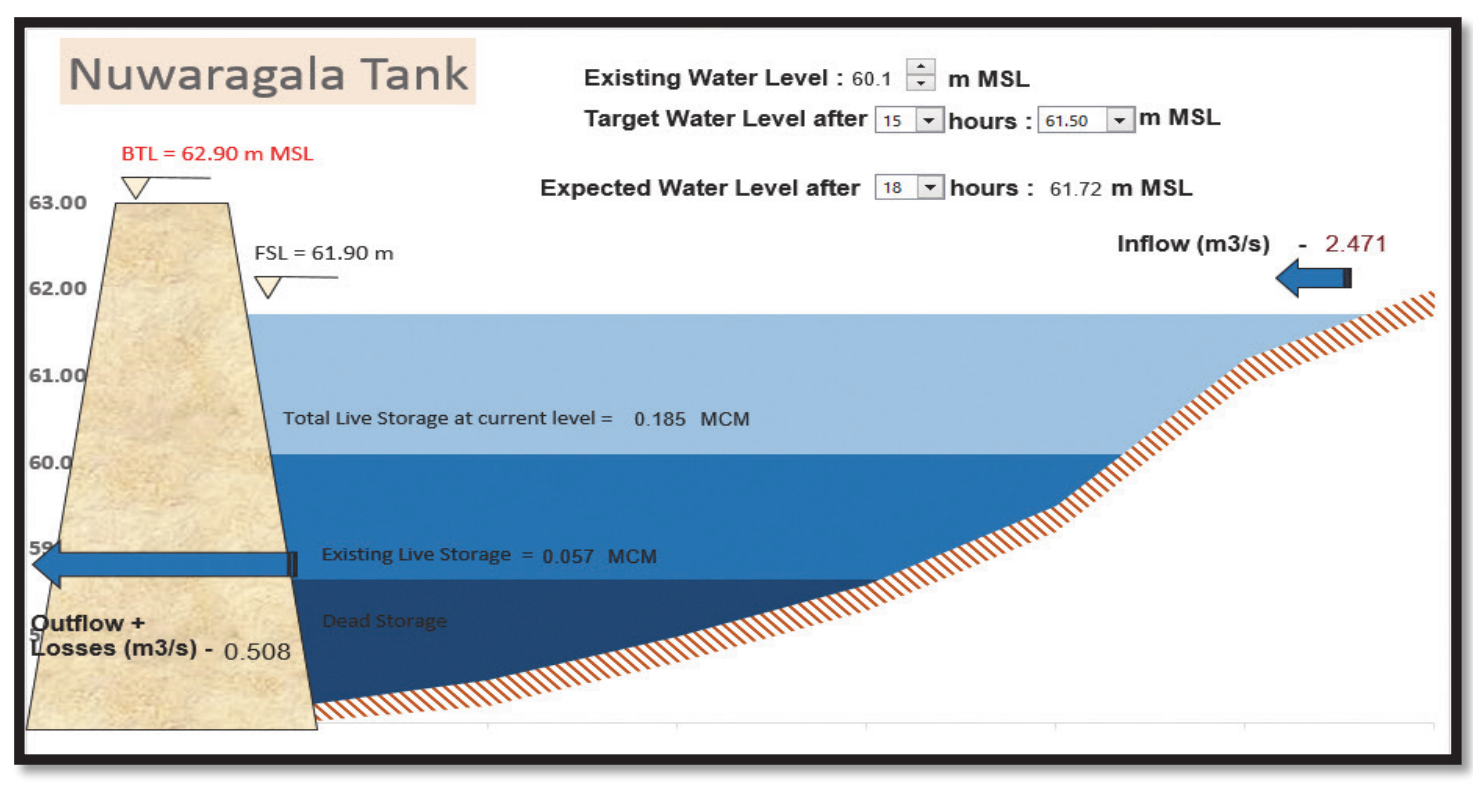

Figure 10 - Example of Reservoir Operation Interface

\subsection{Setting Operational Targets}

Operational targets are set by the Model as shown in Figure 8.

\subsubsection{Measuring flumes}

The hydraulic head that has to be maintained at the measuring well of the flume is given. See data row 1 of Figure 8.

\subsubsection{Measuring Weirs}

The hydraulic head that has to be maintained at the measuring weir is given. See data row 2 of Figure 8.

\subsubsection{Cross regulators}

The cross regulators in the system are designed as upstream control structures. Allowing the operation strategy to work, the Model gives the hydraulic head that has to be maintained $\mathrm{u} / \mathrm{s}$ to the cross regulator. See data row 10 of Figure 8.

\subsubsection{Reservoir Water Levels}

The operation target of the reservoir is the desired storage denoted by the surface water level. The Model has facility to increase or decrease the reservoir storage targeting a set water level. The reservoir inflow is adjusted accordingly and the operation targets $\mathrm{u} / \mathrm{s}$ to the reservoir are updated (see Figure 10). See data rows $3 \& 4$ of Figure 8 . Current water level, target (expected) water level and the additional inflow are shown.

In the reservoir operation interface, the tentative time of occurrence of any spillage is predicted provided the additional flow is not curtailed. It is very much helpful to the scheme 
operators to avoid unnecessary spillages causing operational losses.

\subsection{Monitoring Performance}

In parallel with the operation, the monitoring of the amount of water used by each Management Block and by every tertiary canal within the Block would be needed. The Model extends the facility for making the managers comfortable with future planning. Two figures in the Appendix 2 show the chart options included in the Model with filtering facilities for Block wise monitoring and Tertiary canal level monitoring.

\subsection{Reporting}

The Model has the capacity to produce following Reports and Forms.
- Operation Sheets

- Daily Water Delivery Record Formats

- Water Ordering Form

- Weekly Water Returns

The inputs from the technical staff required to produce these reports are eliminated by the Model. It is a considerable saving to the management.

\section{Operational Strategies}

\subsection{Staff Deployment}

When the canals are in the operation phase, the reporting of daily water deliveries to the Main

- Block wise Irrigation Schedules

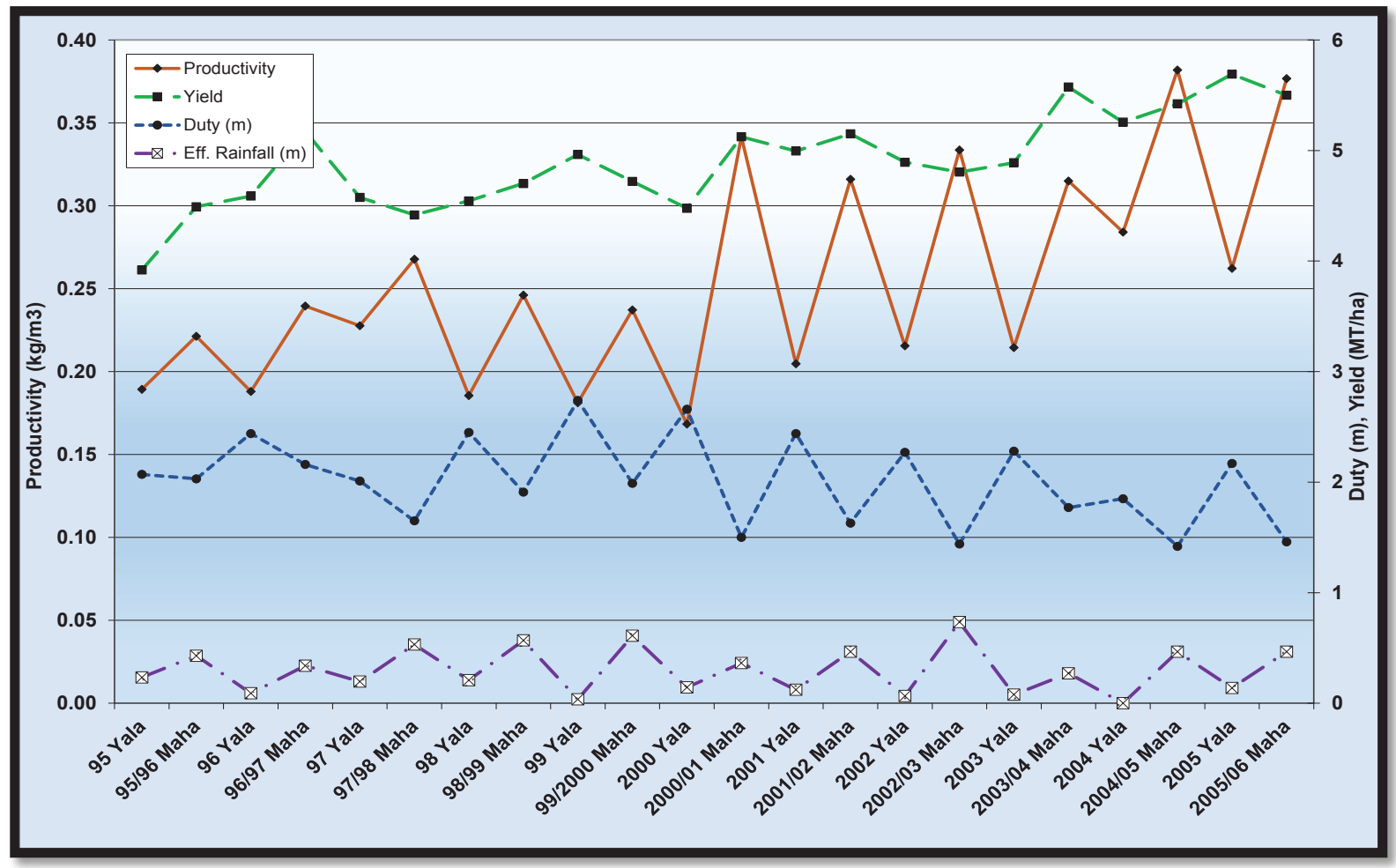

Figure 11 - Seasonal Water Delivery and Productivity performance of 22 cultivation seasons Note 4 - Water use data - WMS, MASL / Yield data - DCES, Treasury of GOSL

Canal Operation office would be done by seven Water Masters (Jalapalaka). One Water Master would be kept on standby at the office. They would be supervised by an Engineering Assistant. The same staff would be engaged in canal operations as well.

\subsection{Sensitivity of the Control Structures}

The sensitivity of each control structure would be different with respect to the discharge changes in the lateral canals.
Due care would be given while operating high sensitive control structures such as offtakes, cross regulators, etc.

\subsection{Crop Responses to the Water Supply}

The response of the crop to the water supply at its different stages is different. In case of paddy the Yield response factor $\left(\mathrm{k}_{\mathrm{y}}\right)$ is 1.2 and 2.4 at the vegetative and flowering periods respectively (FAO, ID33, 1979). When $\mathrm{k}_{\mathrm{y}}>1.0$, the relative yield decrease is larger than the relative reduction in evapotranspiration. The crop is sensitive to the water stresses during these periods. 
This is taken into account during the operations in the scheme.

\subsection{Use of effective rainfall}

Rainfall measurements are taken daily at six gauging stations representing each management block. Approximate irrigable area covered by one gauging station is 2,800 ha.

Daily measurements are entered into the model and the effective rainfall values are observed. The irrigation water requirements are re assessed and the canal water deliveries are adjusted accordingly applying appropriate percentage reductions.

\section{Field Application of the Model}

This Model was tested in the field for six cultivation seasons starting from 2003 Yala. The improvements identified during its application were made keeping the Model performance close to the real hydraulic behaviour of the Canal system.

\subsection{Outcome of the application}

The final outcome of the field application of this Model is graphically presented in Figure 11. The significant facts seen there are;

- efficient use of irrigation water,

- efficient use of effective rainfall,

- high yields with less irrigation water,

- trend towards increasing water productivity.

One of the hidden reasons towards high yields with comparatively less irrigation water is the operation schedules prepared by the Model considering the growth stages of the crop. Crop coefficients were neglected in the previously used operation schedules.

The effective rainfall is efficiently consumed in the system during the cultivation season by using the flexibility given by the Model to reschedule operations daily.

Figure 13 gives the comparison of irrigation water consumption with the allocation up to week No 18 of the cultivation season Yala 2005.

Appendix 3 shows the long term behaviour of water usage in System C, during Yala \& Maha seasons.

\section{Conclusions}

The tailor-made mathematical model of an irrigation canal network is a user-friendly management tool for scheduling, operating, monitoring and reporting irrigation water supply to the tertiary canals in major irrigation schemes. It is a fairly new concept that has been tested in the field and has produced attractive results. It is anticipated that this Model will be a useful tool for managing irrigation systems.

\section{Acknowledgement}

The author wishes to record his appreciation to the management in System C and Mahaweli Authority of Sri Lanka for allowing to test the Model. I would also like to thank my subordinates Mr. Senadeera (Engineering Assistant - Operation), Ms. Priyangika (Engineering Assistant - Data Entry), eight Water Masters and two Drivers working very devoted manner during field applications of the Model.

\section{References}

1. Newell, F. H., Irrigation Management,D. Appleton and Co., New York - London, 1916.

2. Malano, Hector M., van Hofwegen, Paul, J. M., Management of Irrigation and Drainage Systems, A. A. Balkema, Rotterdam, 1999, pp. 4-5.

3. Analysis Report of the First Benchmark Survey of Mahaweli System C Upgrading Project, IWMI, October 2004, p. 3, pp 38-39

4. Siriwardana, S. M. P., Operational Performance Monitoring in System ' $\mathrm{C}$ ' of the Mahaweli Development Programme in Sri Lanka, M.Sc. Thesis HH 440, May 2002, p. 13, p. 20, Annex II

5. Operation and Maintenance Manual for System C of Mahaweli Development Project, Nippon Koei Co. Ltd., March 1991, pp 4.2-4.16, p 4.17,

6. Ponrajah, A. J. P., Design of Irrigation Headworks for Small Catchments, 2ndEdition, Irrigation Department, Colombo, 1984

7. FAO, Effective Rainfall, Irrigation and Drainage Paper 25, Rome, 1974

8. FAO, CROPWAT 4.0 Software

9. Canals and Related Structures, Design Standard No. 3, USBR, Colorado, 1967

10. Doorenbos, J., Kassam, A. H., Yield response to Water, FAO Irrigation and Drainage Paper nr. 33, FAO, Rome, 1979, p. 193 


\section{Appendix1}

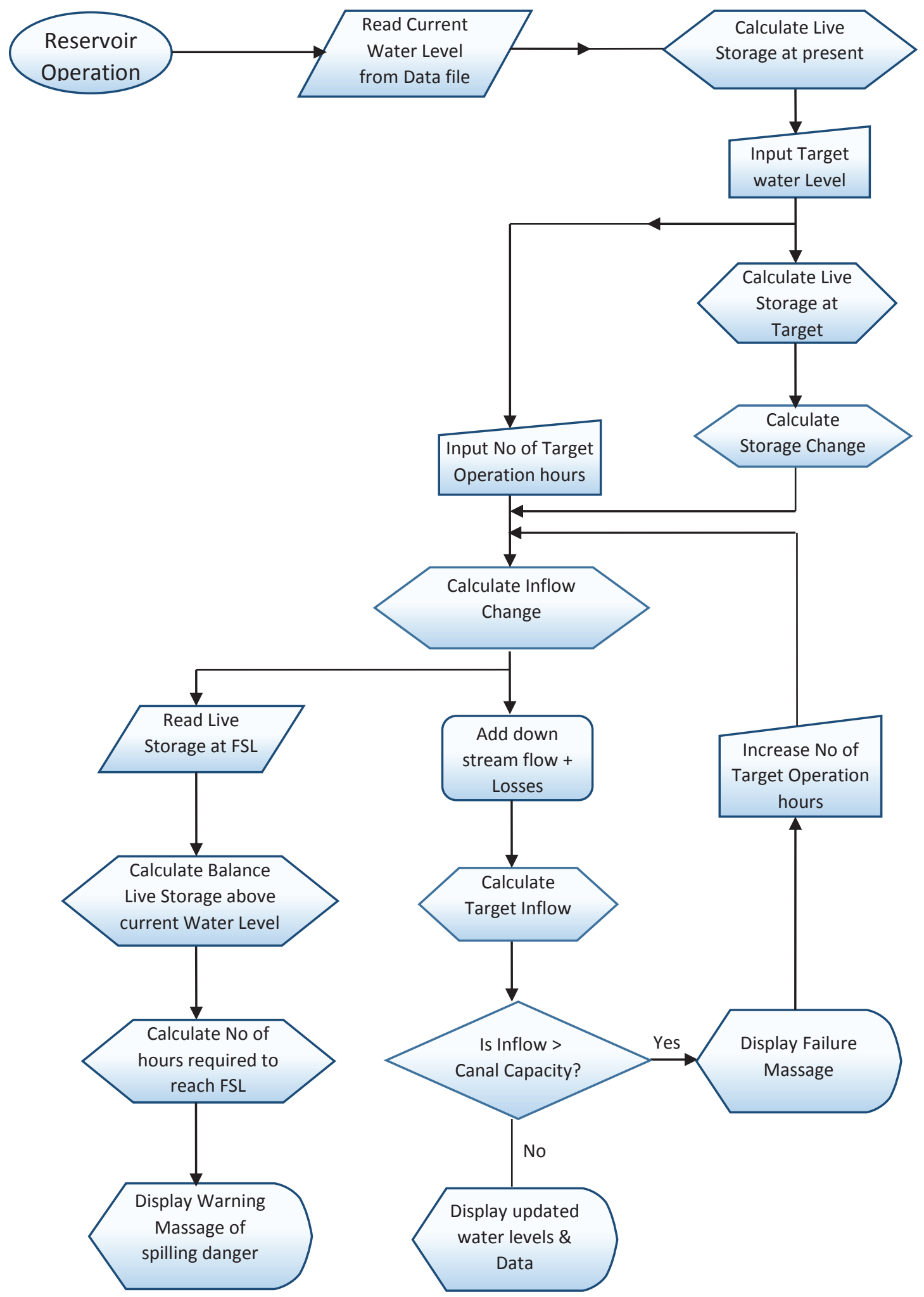

Figure 12 - Conceptual Flow Diagram of the element Reservoir Operation 


\section{Cultivation Season Yala 2005}

Appendix 2

Irrigation water Allocation and Consumption,

at the end of week number 18

Last Updated on :01/09/2005.

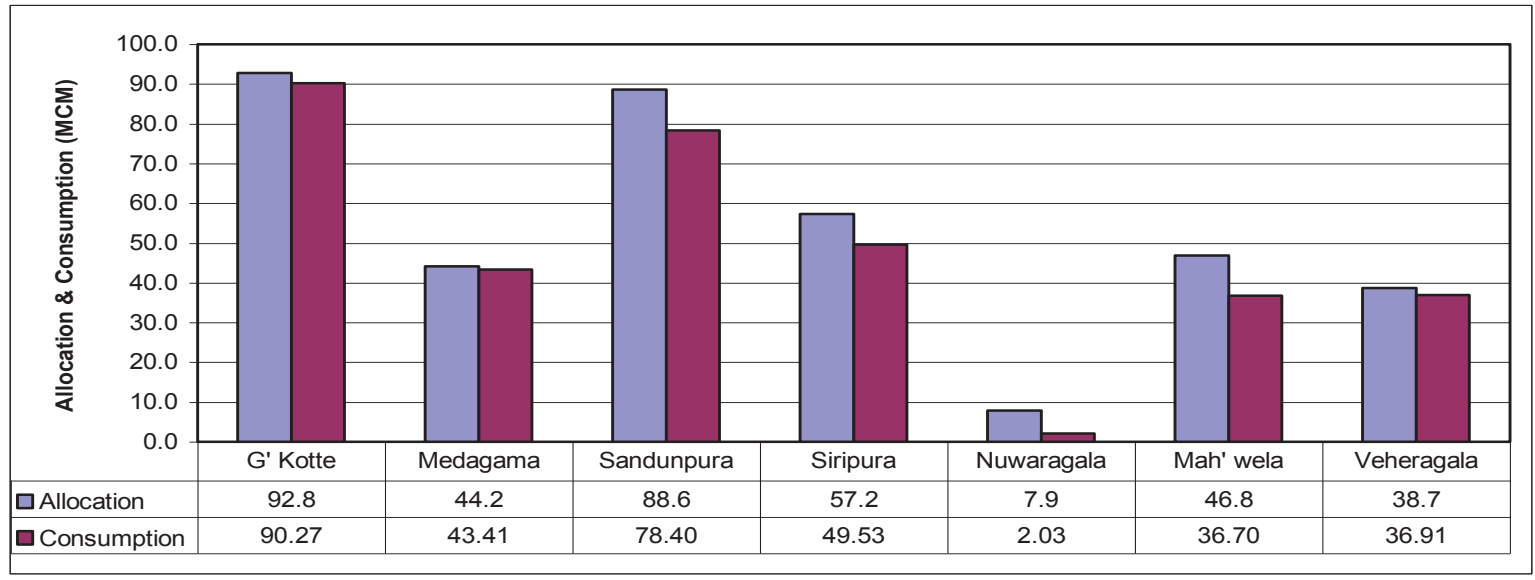

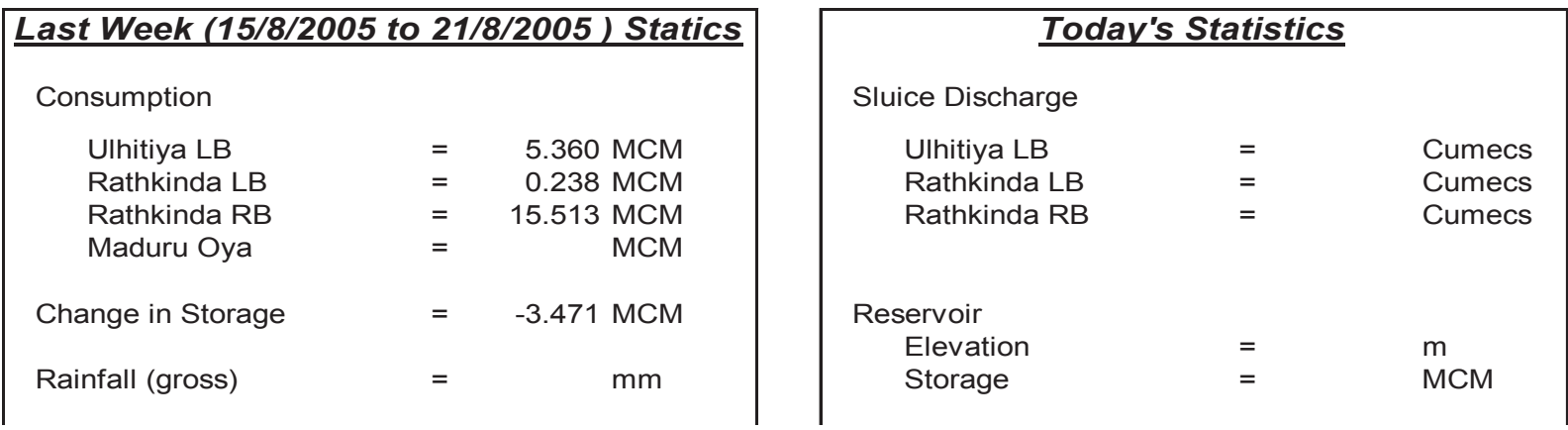

Figure 13 - Chart tool for monitoring Management Block level water use performance

Weekly Water Consumption Scheduled vs Issued

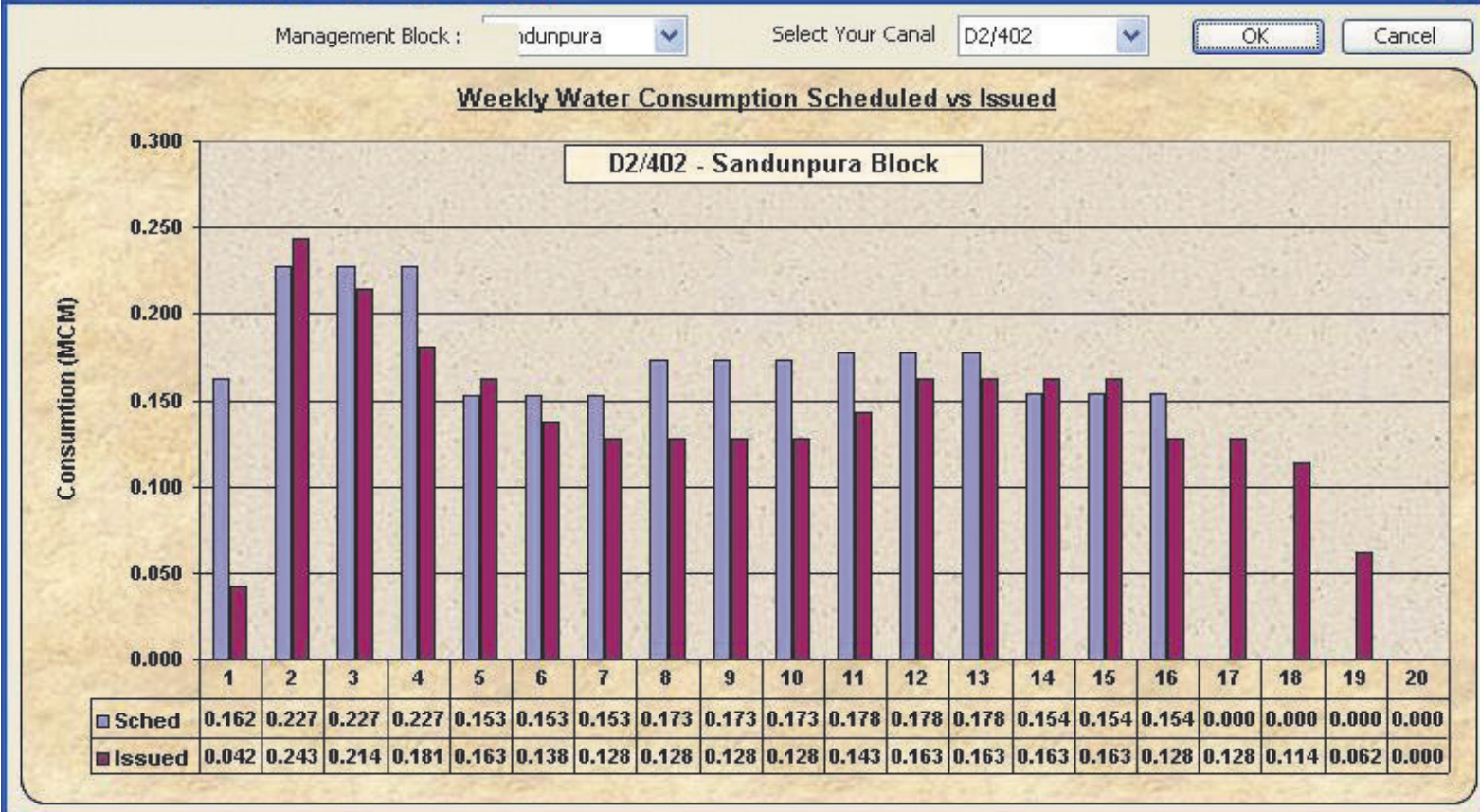

Figure 14 - Chart tool for monitoring Tertiary canal water use performance 


\section{Appendix 3}

Sluice Duty at Ulhitiya/Rathkinda - Yala Seasons, System C
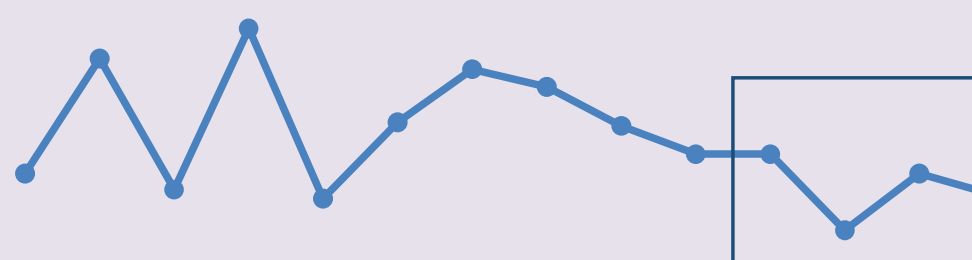

Field Tested Period

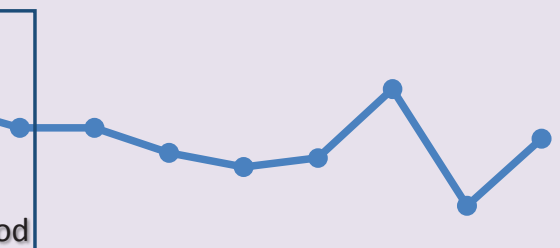

199319941995199619971998199920002001200220032004200520062007200820092010201120122013

Figure 15 - Water usage in System C - Yala Seasons

Sluice Dty at Ulhitiya Rathkinda - Maha Seasons, System C

2.5

2.0

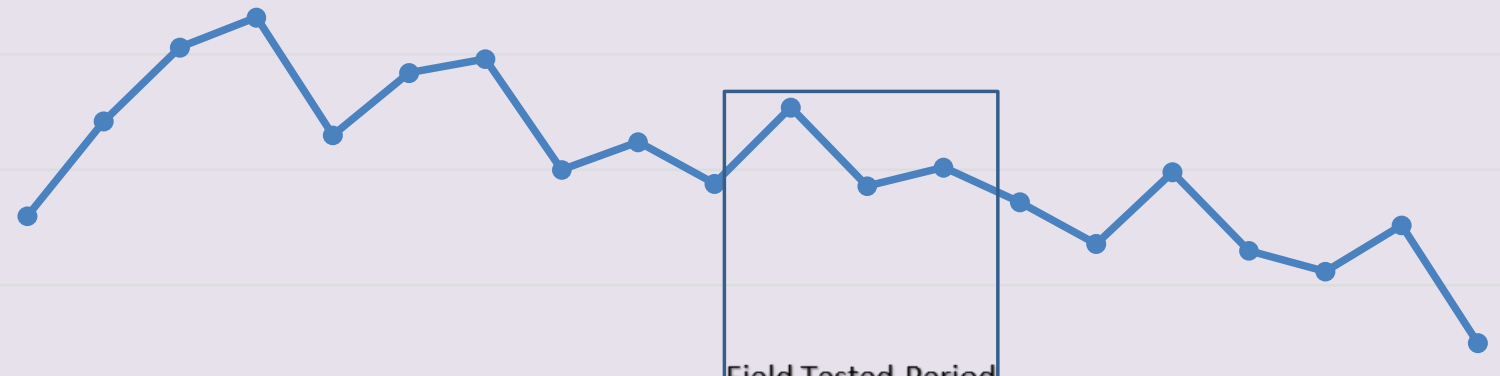

0.5

Field Tested Period

0.0

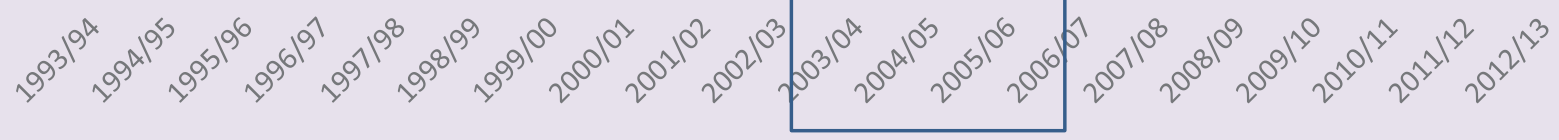

Figure 16 - Irrigation Water Usage in System C - Maha Seasons 